\title{
Impact of coalition and insurgent force levels on civilian deaths and injuries in Iraq, 2003-2005
}

\author{
K. H. Tiedemann \\ Applied Economics and Simon Fraser University, Canada
}

\begin{abstract}
War and civil conflict are major causes of deaths and injuries among civilian populations in many countries. While the main focus to date in analysis of the Iraq insurgency has been on deaths among the Coalition, Iraqi and insurgent forces, the conflict has had a major toll on the civilian population of Iraq. This study attempts to partially redress this imbalance by examining the impact of the insurgency on civilians. The study uses time-series analysis to model the impact of coalition and insurgent troop levels on three main indicators of civilian well being: the number of violent incidents per month, the frequency of externallycaused civilian death, and the number of bombing-related civilian injuries in Iraq, for the period May 2003 to October 2005.

Keywords: civilian deaths, civilian injuries, war related risks, regression models, two-stage least squares.
\end{abstract}

\section{Introduction}

War and civil conflict are major causes of death and injury among civilian populations in a number of countries. Although a large descriptive and analytical literature has examined the causes, nature and impact of war and civil conflict, there have been relatively few attempts to quantitatively model the impacts of troop levels on risks to civilian populations. Such information can potentially assist in the development of strategies to minimize the impact of war and civil conflict on civilians.

This study uses time-series analysis to model the impact of Coalition and insurgent troop levels in Iraq on three main indicators of civilian well being: the number of violent incidents per month, the frequency of externally-caused 
civilian death, and the number of bombing-related civilian injuries in Iraq, for the period May 2003 to October 2005. Both ordinary least squares and two-stage least squares models are estimated, with the latter allowing for the possibility that insurgent troop levels are determined within the model rather than being exogenous.

\section{Previous research}

Over the past three years, there has been a large literature on the nature, consequences and implications of the Iraq insurgency. Despite the considerable size of this literature, the impact of the Iraqi insurgency and the coalition counter insurgency on the civilian population of Iraq has been less comprehensively examined. In his review of the chronology of the insurrection, Cordesman [1] briefly examined the pattern of civilian deaths. He noted that the Pentagon [2], in an October 2005 report to Congress, concluded that "Approximately $80 \%$ of all attacks are directed against Coalition Forces, but $80 \%$ of all casualties are suffered by Iraqis." Cordesman [1] further noted that reanalysis of Pentagon data suggested that at least 13 Iraqi civilians were killed for every US soldier killed in Iraq.

Iraq Body Count [3] estimated that some 25,000 Iraqi civilians were killed in 2003 and 2004 with one-third killed by Coalition troops. Tavernise [4] reported on Iraqi Ministry of Health statistics for the period November 2004 through early April 2005 which provides some information on the patterns of deaths and injuries. In particular, Baghdad accounted for about one-third of Iraqi deaths, the highest per capita death rates were in Al Anbar, Najaf and Diyala and there were about four times as many reported Iraqi wounded as reported Iraqi deaths for this period. O'Hanlan and Kamp [5] of the Brookings Institution have provided the most detailed indicators of violent incidents, civilian injuries and civilian deaths.

\subsection{Data and approach}

Based on a review of recent studies of insurgencies as well as reporting on the insurgency in Iraq, six key issues were identified for study. These six issues can be summarized as follows: (1) examine nature and number of violent incidents; (2) examine nature and distribution of deaths; (3) examine nature and distribution of civilian injuries; (4) determine impact of Coalition force levels on incidents, deaths, injuries; (5) determine impact of insurgent force levels on incidents, deaths, injuries; and (6) determine impact of Iraqi force levels on incidents, deaths, injuries. Table 1 summarizes the study issues, data sources and methodologies used for this study.

Consider the following model of insurgent activity where monthly incidents, civilian deaths or injuries are a positive function of insurgent attacks and a negative function of coalition patrols, with months subscripted by $\mathrm{m}$. Insurgent attacks $\left(\mathrm{A}_{\mathrm{m}}\right)$ are positively related to insurgent force levels $\left(\mathrm{I}_{\mathrm{m}}\right)$ through equation (1). 
Table 1: $\quad$ Study issues, data sources and methodologies.

\begin{tabular}{|l|l|l|}
\hline Study Issue & Data Sources & Methodologies \\
\hline $\begin{array}{l}\text { Number and distribution of } \\
\text { violent incidents }\end{array}$ & Literature review & Trend analysis \\
\hline $\begin{array}{l}\text { Number and distribution of } \\
\text { civilian deaths }\end{array}$ & Literature review & Trend analysis \\
\hline $\begin{array}{l}\text { Number and distribution of } \\
\text { civilian injuries }\end{array}$ & Literature review & Trend analysis \\
\hline $\begin{array}{l}\text { Impact of Coalition force } \\
\text { levels }\end{array}$ & $\begin{array}{l}\text { Brookings Institution } \\
\text { database }\end{array}$ & $\begin{array}{l}\text { OLS and 2SLS } \\
\text { regressions }\end{array}$ \\
\hline $\begin{array}{l}\text { Impact of insurgent force } \\
\text { levels }\end{array}$ & $\begin{array}{l}\text { Brookings institution } \\
\text { database }\end{array}$ & $\begin{array}{l}\text { OLS and 2SLS } \\
\text { regressions }\end{array}$ \\
\hline Impact of Iraqi troop levels & $\begin{array}{l}\text { Brookings Institution } \\
\text { database }\end{array}$ & $\begin{array}{l}\text { OLS and 2SLS } \\
\text { regressions }\end{array}$ \\
\hline
\end{tabular}

$$
\mathrm{A}_{\mathrm{m}}=\gamma_{1} \mathrm{I}_{\mathrm{m}}
$$

Coalition patrols $\left(\mathrm{C}_{\mathrm{m}}\right)$ are positively related to coalition troop levels $\left(\mathrm{T}_{\mathrm{m}}\right)$ through equation (2).

$$
\mathrm{C}_{\mathrm{m}}=\gamma_{2} \mathrm{~T}_{\mathrm{m}}
$$

The production function for monthly incidents, deaths or injuries $\left(D_{m}\right)$ is a CobbDouglas function in attacks and patrols so that substituting for $A_{m}$ and $C_{m}$ we have (3)

$$
D_{m}=K\left(A_{m}\right)^{\alpha}\left(C_{m}\right)^{\beta}=K\left(\gamma_{1} I_{m}\right)^{\alpha}\left(\gamma_{2} T_{m}\right)^{\beta}=K \gamma_{1}^{\alpha} \gamma_{2}^{\beta}\left(I_{m}\right)^{\alpha}\left(T_{m}\right)^{\beta}
$$

Then renaming the consolidated constant $\mathrm{k}$ and taking logs on both sides of (3), we have (4)

$$
\log \left(D_{m}\right)=k+\alpha \log \left(I_{m}\right)+\beta \log \left(T_{m}\right), \text { where } \alpha>0, \beta<0 .
$$

We assume that $T_{m}$ is exogenous in (4) since coalition troop levels are limited by the ability of coalition partners, in particular the American Army and Marine Corps, to field troops. But we assume that $I_{m}$ is potentially endogenous since high levels of insurgent success, as evidenced by high death and injury rates, could lead to higher recruitment levels of insurgents. Since ordinary least squares estimation of the parameters in (4) could potentially yield biased and inconsistent estimates of the parameters, an estimation method dealing with the potential endogeneity of insurgent force levels, such as two-stage least squares, may be appropriate. In the event, we estimate a number of variants of (4), with violent incidents, civilian deaths and civilian injuries as outcome variables, using both ordinary least squares and two-stage least squares. In the two-stage least squares equations, the lagged values of the insurgent force levels are used as instruments. 
In additional modeling, not reported here, we attempted to determine the impact of Iraqi troop levels on the outcome variables. This modeling did not find a statistically significant impact of Iraqi troop levels on the number of violent incidents, civilian deaths or civilian injuries. A number of statements by American military spokespersons through October 2005 indicated that the readiness of Iraqi troops was extremely low (Fallows [6]. This may explain the lack of a measurable impact of Iraqi troop levels on outcomes (see Semple [7]).

\section{Trends in incidents, deaths and injuries}

On May 1, 2003, President Bush announced an end to major operations in Iraq. But with the end of organized resistance on the part of the Iraqi army, the insurgency was beginning to find its feet. Table 2 provides the framework within which the evolution of the insurgency is briefly reviewed, with a focus on the impact on civilians. This discussion draws heavily on the reviews by Beckett [8], Cordesman [9], Fallows [10] and Metz [11].

Table 2: $\quad$ Major phases of the insurgency in Iraq.

\begin{tabular}{|l|l|l|}
\hline Phase & Date & Description \\
\hline Phase 1 & May03 - Sep03 & $\begin{array}{l}\text { Beginning of the insurgency. Coalition } \\
\text { attacks result in widespread civilian deaths } \\
\text { with beginning of small arms attacks on } \\
\text { Coalition forces by insurgents }\end{array}$ \\
\hline Phase 2 & Oct 03 - June 04 & $\begin{array}{l}\text { Bombing campaign. Increased insurgent } \\
\text { emphasis on improvised explosive devices } \\
\text { with increase in civilian deaths and injuries }\end{array}$ \\
\hline Phase 3 & July 04 - Jan05 & $\begin{array}{l}\text { Escalation of the insurgency. Dramatic } \\
\text { increase in insurgent forces and incidents } \\
\text { with a further jump in civilian casualties }\end{array}$ \\
\hline Phase 4 & Feb05-Oct05 & $\begin{array}{l}\text { Intra-Iraqi conflict. Increased targeting of } \\
\text { the Shiite civilian population by Sunni } \\
\text { insurgents with escalating Shiite revenge } \\
\text { attacks on Sunni civilians }\end{array}$ \\
\hline
\end{tabular}

Phase 1 (May 2003 - September 2003). Beginning of the Insurgency. As Metz [10] points out, American strategists underestimated both the effort required to secure and stabilize Iraq and how quickly resentment of the occupation would lead to violence directed against coalition forces. In the first phase of the insurgency, civilians were not specifically targeted by the insurgency, and most civilian deaths and injuries appear to be collateral damage of Coalition and insurgent attacks. Table 3 provides information on key measures of the impact of the insurgency. Note that information on civilian injuries is available only for multiple fatality (three or more deaths) bombings. As Table 3 shows, civilian deaths ran at a rate of about 79 per month during 
Phase 1, with injuries due to multiple fatality bombings running at a similar rate. The number of violent incidents per day rose steadily averaging about 15 per day for Phase 1 as a whole.

Table 3: $\quad$ Key variables by phase, monthly averages.

\begin{tabular}{|l|l|l|l|l|}
\hline & Phase 1 & Phase 2 & Phase 3 & Phase 4 \\
& $2003: 05$ & $2003: 10$ & $2004: 07$ & $2005: 02$ \\
& $2003: 09$ & $2004: 06$ & $2005: 1$ & $2005: 10$ \\
\hline Coalition & 166,200 & 152,780 & 165,800 & 165,670 \\
forces & $(7,328)$ & $(8,217)$ & $(5,774)$ & $(7,697)$ \\
\hline Civilian & 79.4 & 263.0 & 416.4 & 509.2 \\
deaths & $(49.3)$ & $(245.6)$ & $(285.1)$ & $(367.9)$ \\
\hline Incidents per & 15.0 & 33.1 & 61.9 & 69.9 \\
day & $(7.2)$ & $(14.0)$ & $(11.5)$ & $(16.9)$ \\
\hline $\begin{array}{l}\text { Insurgent } \\
\text { forces }\end{array}$ & 5,000 & 6,889 & 19,714 & 17,889 \\
\hline Civilians & $(0)$ & $(4622)$ & $(756)$ & $(1746)$ \\
bomb wound & $(125.0)$ & 269.4 & 267.0 & 527.1 \\
\hline $\begin{array}{l}\text { Multiple } \\
\text { fatality }\end{array}$ & $(1.6$ & $(160.9)$ & $(119.1)$ & $(291.2)$ \\
bombings & $(1.81)$ & $(4.3)$ & 16.1 & 28.9 \\
\hline Iraqi forces & 25,474 & 115,030 & $(5.8)$ & $(10.7)$ \\
& $(16,723)$ & $(24,850)$ & $(1,692)$ & $(21,093)$ \\
\hline
\end{tabular}

Phase 2 (October 2003 - June 2004). Bombing Campaign. In Phase 2, the insurgency reduced its emphasis on small arms and grenade attacks on coalition forces. Increased levels of bombings were the response to the technical superiority of Coalition forces, but as early as August 2003 the propaganda value of bombings was demonstrated with the destruction of the United Nations compound and the consequent removal of UN officials. By spring 2004, the Coalition faced opposition from the Sunnis in central Iraq and the Shiites in the south. The US Central Command reported that during the period May 2003 March 2004, the distribution of US force fatalities was as follows: bombs including improvised explosive devices, 30.8\%; stand-off weapons including rocker-propelled grenades and mortars, 14.3\%; downed helicopters, $13.1 \%$; small arms and grenades, 13.1\%; non-hostile causes, 30.6\% (see Beckett [8]). The increase in bombings had devastating impacts on Iraqi civilians, as violence increased (see Hoffman [12]), deaths rose to 263 per month and woundings due to bombings rose to 269 per month in Phase 2. The number of violent incidents per day more than doubled from Phase 1, reaching about 33 per day.

Phase 3 (July 2004 - January 2005). Escalation of the Insurgency. Through the second half of 2004, the insurgents escalated the conflict as the number of Zarqawi-led attacks increased, and there was evidence of infiltration of Iraqi security forces including the murder of army recruits by insurgents dressed in Iraqi uniforms (see Cordesman [1]). There were increased attacks on foreign 
nationals, Iraqi contractors and Iraqi civilians. Civilian deaths increased to 416 per month while civilian woundings due to bombings was fairly stable at 267 per month in Phase 3. Violent incidents increased to 62 per day.

Phase 4 (February 2005 - December 2005). Intra-Iraqi Conflict. With the elimination of major insurgent strongholds, Coalition efforts in Phase 4 focused on clearing insurgent forces from the area bordering Syria (see Kagan [13]). As Kagan notes, the Coalition strategy of lighting raids to kill or capture insurgents has the advantage of preventing the insurgents from establishing permanent safe havens but the disadvantage of failing to create safe and secure zones for Iraqis. Indeed, in Phase 4, the insurrection began to take on the character of a low-level civil war with increasing attacks by Sunnis on Shiite civilians leading to revenge attacks by Shiites on Sunni civilians. From February 2005 to October 2005, civilian deaths increased to 509 per month while civilian woundings due to bombings increased to 527 per month. The number of violent incidents increased to almost 70 per day during the period, further eroding the security of Iraqi civilians.

\section{Determinants of incidents, deaths and injuries}

Table 4 examines the effect of determinants of the log of coalition force levels and the log of insurgent force levels on the log of violent incidents. The results for the ordinary least squares regression are shown in the second column, while the results of the two-stage least squares regression are shown in the third column. The regression coefficients are the elasticities of violent incidents with respect to force levels, with the standard errors of the coefficients in parentheses below the coefficients. The probability for $F$ is shown below the $F$ value in parentheses. Finally one, two or three asterisks on the coefficient indicate that the coefficient is significant at the $10 \%, 5 \%$ or $1 \%$ level respectively.

The explanatory power of the regressions is significant as measured by either the R-squared values adjusted for degrees of freedom or the F-test, although the $\mathrm{R}$-squared value for the two-stage least squares regression does not have the usual interpretation as the share of the variance explained by the regression. Both regressions have good fits, the only problem being the low values of the DurbinWatson statistics suggesting the presence of autocorrelation. This probably reflects the fact that insurgent attacks tend to come in clusters over several months followed by lower activity levels during periods of re-grouping. This tends to make the errors or shocks correlated over time rather than uncorrelated. Fitting a first-order autoregressive scheme to the errors did not help.

In both the OLS and 2SLS models, the coefficients have the expected signs and are statistically significant. An increase in the size of the coalition force reduces the number of violent incidents while an increase in the size of the insurgent force increases the number of violent incidents. Several observations on these results are in order. First, the results of the OLS and 2SLS least squares models are reasonably similar. This suggests that simultaneous equation bias may not be a major issue. Second, the elasticity of violent incidents with respect to the size of the insurgent force is 0.97 for the OLS model and 1.26 for the 
2SLS model. This seems quite reasonable, since other things equal, a $1 \%$ increase in the size of the insurgent force increases the effectiveness of the insurgent force by $1 \%$. Third, the elasticity of violent incidents with respect to the Coalition force is quite high at 3.25 for the OLS model and 4.90 for the 2SLS model. This suggests that increasing Coalition force levels, within the constraints imposed by the size of the standing armies of the members of the Coalition, could have a significant impact on the number of violent incidents and consequently the level of security in Iraq. In particular, this finding provides no support for the widely expressed view that the level of Coalition forces is the problem in the sense that largely Coalition forces provide more targets and create more resentment among the local population leading to additional violent incidents.

Table 5 examines the effect of determinants of the log of coalition force levels and the log of insurgent force levels on the log of civilian deaths. The regressions have significant explanatory power and the Durbin-Watson statistics, although still low, are better than for the models of incidents. In both the OLS and 2SLS models, the coefficients have the expected signs and three of the four coefficients on exogenous variables are statistically significant. An increase in the size of the coalition force reduces the number of civilian deaths, while an increase in the size of the insurgent force increases the number of civilian deaths. The observations are similar to those for the previous model. First, the results of the OLS and 2SLS least squares models are reasonably similar so that simultaneous equation bias may not be a major issue. Second, the elasticity of civilian deaths with respect to the size of the insurgent force is 1.05 for the OLS model and 1.15 for the 2SLS model, suggesting that a $1 \%$ increase in the size of the insurgent force increases the effectiveness of the insurgent force by $1 \%$. Third, the elasticity of the Coalition force is quite high at 3.10 for the OLS model and 3.67 for the 2SLS model, but the significance levels are smaller than for the models of violent incidents.

Table 4: Determinants of violent incidents per day.

\begin{tabular}{|l|l|l|}
\hline & OLS & 2SLS \\
\hline Constant & $33.66^{*}$ & $50.78^{* *}$ \\
& $(14.91)$ & $(23.21)$ \\
\hline Logcoaforce & $-3.25^{* *}$ & $-4.90^{* *}$ \\
& $(1.46)$ & $(2.18)$ \\
\hline Logincforce & $0.97^{* * *}$ & $1.26^{* * *}$ \\
& $(0.14)$ & $(0.36)$ \\
\hline Adjusted $\mathrm{R}^{2}$ & 0.73 & 0.66 \\
\hline DW & 1.17 & 1.26 \\
& $(0.42)$ & $(0.37)$ \\
\hline $\mathrm{F}(2,27)$ & 40.7 & 29.4 \\
& $(0.00)$ & $(0.00)$ \\
\hline
\end{tabular}


Table 5: $\quad$ Determinants of civilian deaths per month.

\begin{tabular}{|l|l|l|}
\hline & OLS & 2SLS \\
\hline Constant & 32.88 & 38.83 \\
& $(21.79)$ & $(39.53)$ \\
\hline Logcoaforce & $-3.10^{*}$ & -3.67 \\
& $(1.95)$ & $(2.77)$ \\
\hline Logincforce & $1.05^{* * *}$ & $1.15^{* * *}$ \\
& $(0.24)$ & $(0.33)$ \\
\hline Adjusted $\mathrm{R}^{2}$ & 0.46 & 0.45 \\
\hline DW & 1.42 & 1.44 \\
& $(0.28)$ & $(0.28)$ \\
\hline $\mathrm{F}(2,27)$ & 13.2 & 13.0 \\
& $(0.00)$ & $(0.00)$ \\
\hline
\end{tabular}

Table 6: Determinants of civilian woundings per month due to multiple fatality bombings.

\begin{tabular}{|l|l|l|}
\hline & OLS & 2SLS \\
\hline Constant & 45.74 & 46.48 \\
& $(34.0)$ & $(32.3)$ \\
\hline Logcoaforce & -3.64 & -3.70 \\
& $(2.83)$ & $(2.69)$ \\
\hline Logbombings & $1.28^{* * *}$ & $1.25^{* * *}$ \\
& $(0.16)$ & $(0.17)$ \\
\hline Adjusted R ${ }^{2}$ & 0.70 & 0.70 \\
\hline DW & 1.78 & 1.78 \\
& $(0.11)$ & $(0.11)$ \\
\hline $\mathrm{F}(2,27)$ & 34.3 & 34.2 \\
& $(0.00)$ & $(0.00)$ \\
\hline
\end{tabular}

Table 6 examines the effect of determinants of the log of coalition force levels and the log of the number of bombings on the log of civilian wounded or injured due to bombings. The log of the number of bombings is used as an explanatory variable in this model because while the number of civilian wounded or injuries due to bombings (in which three or more civilians were killed) is available, the total number of civilian wounded or injured is not available, since no comprehensive statistics are complied. The regressions have significant explanatory power and the Durbin-Watson statistics are reasonable. In both the OLS and 2SLS models, the coefficients have the expected signs and the coefficients on the log of bombings are significant. The coefficients on the log of coalition forces are not significant but are larger than the standard errors. An increase in the size of the coalition force may reduce the number of civilian wounded, while an increase in the number of bombings increases the number of civilians wounded. The observations are similar to these for the previous models. First, the results of the OLS and 2SLS least squares models are 
reasonably similar. Second, the elasticity of civilian wounded with respect to the number of bombings is 1.28 for the OLS model and 1.25 for the 2SLS model. Third, the elasticity of civilian wounded with respect to size of the Coalition force is 3.64 for the OLS model and 3.70 for the 2SLS model.

\section{Conclusions}

Key findings of this study include the following. First, from May 2003 through October 2005, the number of violent incidents has risen from about 450 per month to over 2,100 per month. Second, the number of civilian deaths has risen from about 80 per month to about 510 per month. Third, the number of civilian injuries due to multiple death bombings has risen from about 80 per month to about 530 per month. Fourth, a 1.0\% increase in coalition troop levels leads to a $3.3 \%$ reduction in violent incidents, a $3.1 \%$ reduction in civilian deaths and a $3.6 \%$ reduction in civilian bombing injuries. Fifth, a $1.0 \%$ increase in insurgent force levels leads to a $1.0 \%$ increase in violent incidents, a $1.1 \%$ increase in civilian deaths and a $1.3 \%$ increase in civilian bombing injuries. Sixth, Iraqi troop levels have had no statistically significant impact on violent incidents, civilian deaths or civilian injuries. Seventh, although Coalition planning for the invasion and initial occupation of Iraq was comprehensive and thorough, the same care did not extend to security planning for the post-war period with little attention paid to mitigating the impacts on civilians.

Some implications of these findings are as follows. First, a reduction in Coalition troop levels before the domestic situation is stabilized, as apparently proposed in recent statements by senior United States government officials, would likely lead to higher levels of civilian deaths and injuries. Second, within the framework used here, there is no statistical evidence that Iraqi army troops are an adequate substitute for Coalition troops in controlling the impacts of the insurgency. Third, the current situation may be an equilibrium in which the insurgents can neither be defeated by nor defeat the Coalition forces, but this equilibrium is characterized by high levels of death and injury among the civilian population of Iraq. Fourth, in planning for any future international military action, appropriate attention needs to be paid to ensuring the safety and security of the civilian population. Fifth, drawing on the experience of recent insurgencies in Northern Ireland, Nicaragua and Guatemala, a negotiated settlement that brings the disaffected into the political process may have some hope of ending the insurgency and the devastation that it is bringing to the civilian population of Iraq.

\section{References}

[1] Cordesman, A. H., Iraq's Evolving Insurgency, Working Draft Revised, Center for Strategic and International Studies, Washington, DC, 2005.

[2] Pentagon, Report to Congress, Measuring Stability and Insecurity in Iraq, July 2005.

[3] Iraqi Body Count, http://www.iraqbodycount.net/press/pr12.php. 
[4] Tavernise, S., "Data Shows Faster-Rising Death Toll Among Iraqi Civilians," New York Times, July 14, 2005.

[5] O'Hanlan, M. E. and N. Kamp, Iraq Index: Tracking Variables of Reconstruction \& Security in Post-Sadam Iraq, www.brookings.edu.

[6] Fallows, J., "Why Iraq Has No Army," Atlantic Monthly, Vol. 296, No. 5, December 2005.

[7] Semple, K., "US Forces Try New Approach: Raid and Dig In," The New York Times, December 5, 2005.

[8] Beckett, I. F. W., Insurgency in Iraq: An Historical Perspective, Strategic Studies Institute, US Army War College, Carlisle, Pa., 2005.

[9] Cordesman, A. H., Iraq: Too Uncertain to Call, Center for Strategic and International Studies, Washington, DC, 2003.

[10] Fallows, J., "Blind into Baghdad," Atlantic Monthly, Vol. 293, No. 1, January-February 2004.

[11] Metz, S., "Insurgency and Counterinsurgency in Iraq," The Washington Quarterly, Vol.27, No.1, Winter 2003-04.

[12] Hoffman, B., Insurgency and Counterinsurgency in Iraq, Rand Occasional Paper, Arlington, Virginia, 2004.

[13] Kagan, F.W., "Fighting to Win: With the Proper Strategy, Victory in Iraq Is More Likely Than People Think," The Weekly Standard, December 9, 2005. 